\title{
Implementation of School-Based Management in Improving Teachers Potential in SMP-IT Nurul ILMI Medan Estate
}

\author{
Azhar Azis \\ Faculty of Psycology Medan Area University \\ azizazhar5@gmail.com
}

\begin{abstract}
The purpose of this study was to find out how the implementation of the school-based management model in the SMP IT Nurul ILMI Medan Estate was carried out. This research was conducted at SMP IT Nurul Ilmi Medan Estate School Academic Year 2018/2019. This research is a descriptive study with a qualitative approach. Sources of research data are Principals, teachers, and staff of SMP IT Nurul ILMI Medan Estate. While secondary data includes documents about student affairs, labor, facilities and infrastructure, school achievements and so on. The method of collecting data in this study are observation, interviews, and documentaries. The results showed that: a) the implementation of School Base Management (SBM) in SMPIT Nurul ILMI Medan Estate was effective because the results obtained from the implementation of SBM could support the achievement of school programs, b) empowerment of prospective teachers in SMP-IT Nurul ILMI Medan Estate focused on prospective teachers in management curriculum; effective learning management; in employment and student affairs; in financial management; and potential teachers in facilities and infrastructure. While the supporting factors for the implementation of schoolbased management are the government, teachers and students. While the inhibiting factors are the role of the community that has not been maximized and the limitations of school funds.
\end{abstract}

Keywords : Management, Based, School, Potential, Teacher

\section{Introduction}

Education is defined as a conscious effort to develop a personality that lasts a lifetime. Education also means a process of helping individual and spiritual bodies towards the formation of a quality main personality. The quality of the person in question is a person who is harmonious, harmonious and balanced in spiritual, moral, social, intellectual, physical aspects and so on.

Since the last few years, we have been introduced to a "new" approach to school management referred to as school based management or in Indonesia referred to as SBM. The emergence of this idea was triggered by the dissatisfaction of education managers at the operational level due to the limited authority they had to be able to manage schools independently. 
In Indonesia, the idea of applying this approach emerged later in line with the implementation of regional autonomy as a new paradigm in the operation of schools. So far, the school is only an extension of the central government bureaucracy to organize political education affairs. The school managers do not have much leeway to operate the school independently. All policies regarding the delivery of education in schools are generally held at the central government level or partly in vertical institutions and schools only accept what they are. Every educational curriculum in the school is central. The principal and teacher must implement each central decision in accordance with the implementation instructions and technical instructions. Through this concept, there are demands to give schools more authority to manage and empower all educational resources in the school and community.

School Based Management (SBM) is a management concept derived from the ability, initiative and creativity of the school. In carrying out education in schools that do not depend on the instructions for all activities for decision making, planning and policy for implementing education is entirely from the initiative of the school itself, not from the bureaucratic layer above it. Rules that limit the authority of schools in administering education, the ability for him to carry out education is an integral part of school ideas and creativity, because schools have the ability to carry out their own tasks.

Our world of education has been introduced to a new approach in school management known as School Based Management (SBM). In Indonesia alone the policy on SBM is not new anymore, which was started in 1999/2000, which was marked by the launch of a grant called Quality Management Operational Assistance (QMOA) which has now changed its term to the fun of School Operational Assistance (Dana BOS).

School Based Management (SBM) is seen as an alternative to the general pattern of school operations which has so far concentrated authority in the central and regional offices. School-based management is a strategy to improve education by delegating important decision-making authority from the center and regions to the school level. Thus School Based Management is basically a management system where the school is an important decision-making unit regarding the implementation of education independently.

School-based management provides greater control opportunities for principals, teachers and parents for the education process in their schools. In the model of school-based management it means that school management tasks are set according to the characteristics and needs of the school itself. Therefore, school citizens have greater autonomy and responsibility for the use of school resources to solve school problems and organize effective educational activities for the long-term development of schools. The main objective is to develop school policy procedures, solve common problems, utilize all potential individuals who are members of the team. So that in addition to being able to print smart and emotionally high school people, they can also prepare development staff. Is a big problem of Indonesia Education is centered on quality. Based on data reached on http://lpmpsumut.kemdikbud.go.id/pmp/pages/main.php?pag e=snp\&id=69899771, show the data the quality of national education 2017. 
Fig 1. National Education Quality, 2017

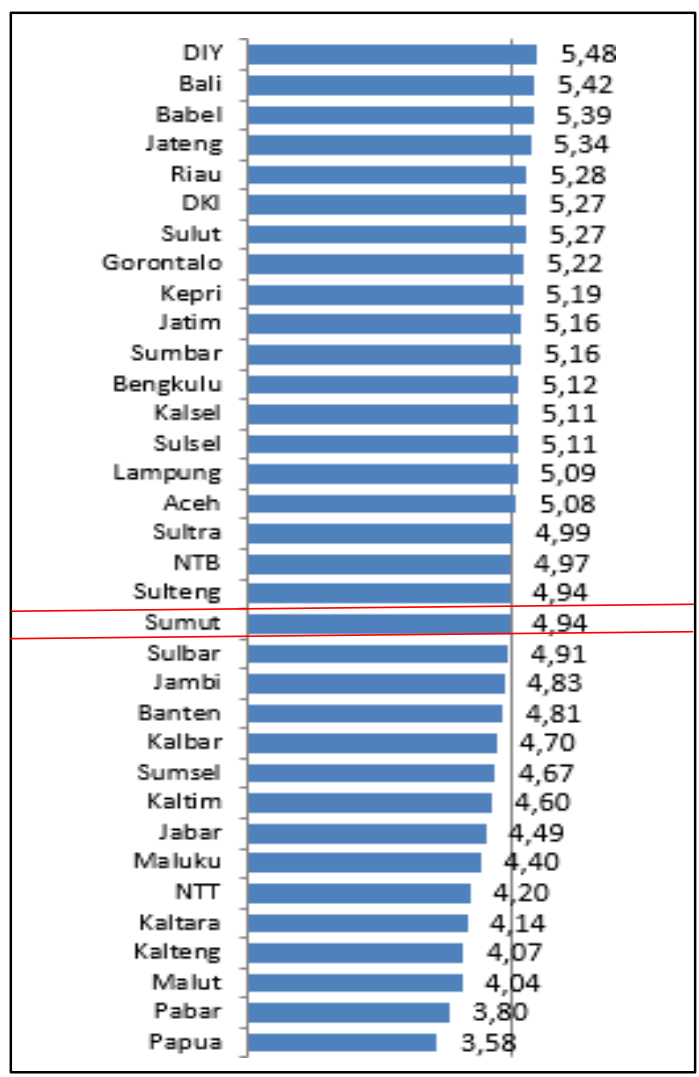

Source : lpmp.sumut.ac.id

Based on the data, North Sumatra has 4,94 point and indicate that is still low. And it needs a solve. The application of management education through SBM must also be able to provide assurance that teachers can develop their ideas in the task / educator to develop themselves professionally as implementers of education, especially at the instructional and institutional level in carrying out the duties and responsibilities assigned to the teacher.

On the one hand, we see many teachers in big cities who have the competence to teach and carry out their duties professionally. However, in many places in the regions and remote areas there are many low- quality educators. This is one reason why the quality of our education is low. But as if the quality of education does not want to be related to the quality of the teacher (Makhmudah, 2016:84) 
Fig 2. Achievement of Education National Standar SMP Nurul ILMI Medan 2017

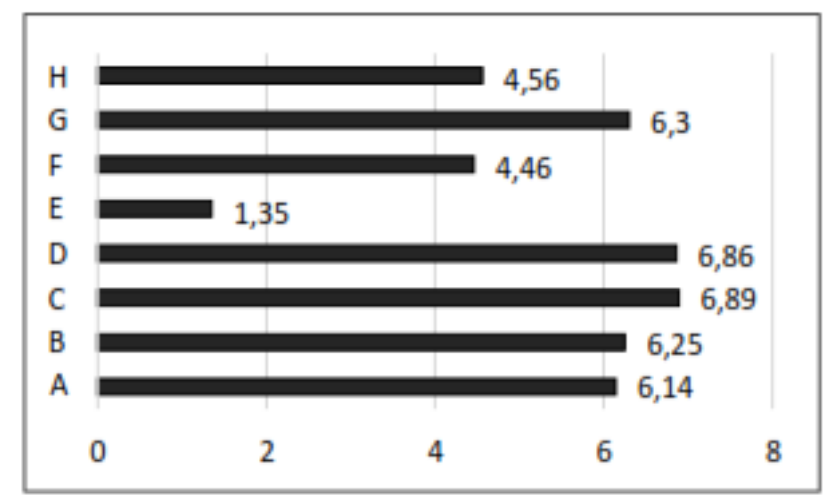

Source : lpmp.sumut.ac.id

Note:
A. Competence of Graduate Standard
B. Content standar
C. Proces Standar
D. Evaluation of Education Standard
E. Educator and education staff standard
F. Facilities and infrastrures standard
G. Education Management
H. Financial Standard

From figure 2 shows that educators and education staff is the lowest $(1,35)$. The low quality of teachers is caused by several important things, such as; certain regions do not have appropriate teachers, the quality of prospective teachers, and the quality of education in the Educator Teaching Institution. Many factors influence the interest in entering and pursuing the teaching profession, including the incentive of less teacher salaries, the perception of the younger generation on the teaching profession and the community's perception of teacher status (Hasibuan, 2004;3). Teacher's profession in Indonesia is less attractive to the potential of the younger generation, even if there is interest in being the second choice. This situation is a setback or loss, "a loss", in the life of thenation.

One of the principals in teacher training is by activating the Subject Teachers' Consultation (MGMP) which aims to provide opportunities for teachers to exchange experiences with other teachers or subject guides. In addition, the Principal supervised the class to see the success of the teacher in the implementation of teaching to support teacher professionalism. But in the implementation of SBM towards teacher empowerment it has not been fully implemented. This is because the management of the Principal is still closed, the lack of transparency between the Principal and the teacher influences the implementation of SBM in empowering teachers. 
The teacher plays a very important role in efforts to develop human resources through education. But the reality is that teachers remain neglected in the realization of empowerment as educational people, especially in terms of self- development, creativity and innovation that are still lacking. Therefore, based on the background of existing problems, the author tries to examine the implementation of School-Based Management in SMP-IT Nurul Ilmi Medan Estate.

\section{Literature Riview}

\subsection{Definition of School Based Management}

School Basic Management is a school management model that provides greater autonomy to the head of the school/madrasah and increases community participation in efforts to improve school performance which includes teachers, students, parents, and the community (Mulyasa, 2003:11). School-based management changes the system of decision- making in transferring authority in decision-making and management to all stakeholders in local stakeholders.

Operationally school-based management can be defined as the implementation of management functions for all components of education in schools. According to Law No. 20 of 2003 concerning National Education System Article 51 Point 1, namely management of early childhood education units, basic education and secondary education is carried out based on minimum service standards with the principle of school-based management.

SBM means a practical approach to redesigning school organizations by giving authority and power to school participation at the local level to advance their schools. Local school participation is nothing but schools, teachers, counselors, curriculum developers, administrators, parents of students, the surrounding community and students themselves. SBM is an alternative form of school as a result of decentralization of education. SBM in principle relies on schools and society and is far from a centralized bureaucracy.

\subsection{Characteristics of SBM}

School-based management has great potential in forming professional principals, teachers and managers of education systems (administrators). Therefore, success in achieving superior performance will be largely determined by the factors of information, knowledge, skills and compensation that are oriented towards quality, efficiency and independence of the school.

The characteristics of SBM can be identified, among others, from how schools can optimize the performance of school organizations, teaching and learning processes, human resource management, and administration. In line with that, based on implementation in developed countries, it was argued that the basic characteristics of SBM were the provision of broad autonomy to schools, high community participation and parents of students. Characteristics of SchoolBased Management according to the government emphasizes management models that provide autonomy to schools in the sense that schools have their own policies to improve the quality of learning in terms of management including training of district-level trainers, training for schools and communities (principals, teachers, and communities), the preparation of the School Development Master Plan (RIPS) and the School Revenue and 
Expenditure Budget (RAPBS) by schools and communities, training for teachers, including direct mentoring in the classroom by teacher trainers (Hasibuan, 2004).

\subsection{Factors Affecting the Implementation of SBM}

The Ministry of Education in collaboration with the World Bank has reviewed several factors that need to be considered in connection with school-based management. These factors are related to: 1) school obligations, 2) government policies and priorities, 3) the role of parents and society, 4) the role of professionalism and managerial, 5) professional development.

\subsection{School Based Management Strategy}

Although SBM has significant obstacles and challenges, there are still various ways that are possible to implement. In this case Rahman (2018) suggests that there are several SBM implementation strategies, namely:

- The granting of school autonomy must have autonomy for four things, namely the possession of autonomy in power and authority, the development of knowledge and skills on an ongoing basis, informal access to all parts and giving awards to each party that succeeds.

- Increasing active community participation in financing, decision-making processes for curriculum and instructional as well as non- instructional. Schools must be more involved in managing schools because after all schools are part of the community at large. Encouraging strong school leadership so that it is able to effectively mobilize and utilize every school's resources, especially Principals must be a source of inspiration for the development and development of schools in general

- Democratic decision-making processes in the life of an active school council.

- All parties are fully aware of their respective responsibilities. To be able to understand this role there must be socialization of the concept of SBM itself.

- There are guidelines from the Ministry of Education so that they can encourage the education process in schools efficiently and effectively.

- The application of SBM is aimed at achieving school goals more specifically is increasing student learning achievement

\subsection{Teacher Empowerment in SBM}

Empowering people means encouraging them to become more involved in decisions and activities that affect their work (Hutabarat, 2016). Thus, it means giving them the opportunity to show that they can give good ideas and have the skills to realize their ideas into reality.

There are at least eight steps of empowerment in relation to SBM, namely:

Arrange groups of teachers as the initial recipients of the empowerment program plan.

Identify by building groups of students at school.

- $\quad$ Select and train teachers and community leaders who are directly involved in the implementation of SBM.

- Forming a school board consisting of school elements, elements of the community under the supervision of the local government. 
- $\quad$ Organizing meetings of members of the school board members.

- Support the activities of groups that are running.

- Developing harmonious relationships between school and society.

- $\quad$ Organizing workshops for evaluation

\section{Metodology}

This research is a descriptive study with a qualitative approach. This research is intended to obtain information about the application of SBM and the form of involvement of community participation carried out by schools in the context of developing schools in SMP-IT Nurul ILMI Medan Estate in depth. The primary data sources of this study are the Principal, teachers, and staff of SMP-IT Nurul ILMI Medan Estate. Whereas with secondary data, among others, documents about student affairs, workforce, facilities and infrastructure, school achievements and so forth. The method of collecting data in this study through observation, interviews, and documentaries. The data analysis tool in this research is qualitative descriptive analysis. Performed through 3 stages; data reduction; presentation of data, and explanation of conclusions.

\section{Result And Discuss}

\subsection{Implementation of School - Based Management in Empowering} Teacher Potential in SMP-IT Nurul ILMI Medan Estate.

In an educational institution / institution, both the institution is under the auspices of the government (State) and independent (Private), elementary, secondary or tertiary level, certainly requires a good (effective and efficient) school management (Bahr et.al, 2007).

Meanwhile to focus more on the goals, SMP-IT Nurul ILMI Medan Estate focused on the objectives of implementing management:

- $\quad$ First, school-based management aims to improve the quality of education through school independence and initiative in managing and providing available resources.

- Secondly, school-based management aims to increase the awareness of school people and the community in the implementation of education through participatory decision making.

- Third, school-based management intends to increase school responsibility to parents, the community, and the government about the quality of their schools.

- $\quad$ Fourth, increasing healthy competition between schools about the quality of education to be achieved

\subsection{Teacher Potential In Curriculum Management}

Curriculum management in junior high schools - IT Nurul ILMI Medan Estate is an activity to realize and adjust the existing curriculum with learning activities. So that learning activities can take place effectively and efficiently. In curriculum planning, headmaster and teachers here form syllabus and teaching programs (Supeni, 2017). Whereas in the implementation of the curriculum, for example in the implementation of teaching and learning activities students can take part in activities related to subjects which according to him are lacking, to face the School Final Examination and National 
Examination for class III, there are additional lesson hours, while for classes I and II if the material lacks mastery, a remedial / repair program is held

\subsection{Potential Of Teachers In Effective Learning Management}

Professional teachers are teachers who successfully carry out the teaching and learning process well and the learning outcomes are in line with expectations (Ambarita, 2016: 56). Besides that teachers are required to always be guided by their professional ethics code in carrying out their work as educators in an effort to achieve 8 national education standards (SNP).

Gagne in Ambarita (2016: 60) says that in achieving effective learning, teachers must be able to use learning media appropriately, because with learning media, students will more easily understand the lesson. Gagne describes the hierarchical level relationship with learning media, where the media is part of six learning stimuli, as in figure 3.



Figure 3. Relationship between learning media and brain stimulation

(Heidt in Ambarita, 2016: 61)

\subsection{Teacher's Potential in Management of Education Personnel}

Management of educators in junior high school-IT Nurul ILMI Medan Estate is an activity to determine the needs of employees, in this case what is meant is the determination of teachers and staff staff. The implementation of the management of educators in the SMP-IT Nurul school of ILMI Medan Estatedi did with recruitment activities, namely by trying to find and get as many prospective employees as possible and then the best and most suitable candidates selected.

Potential of Teachers in Student Management In an effort to implement SMP-IT School-Based Management Nurul ILMI Medan Estate also conducts student management or student management in the form of structuring and regulating activities related to the acceptance of new students in SMP-IT Nurul ILMI Medan Estate. Student management at SMP-IT Nurul ILMI Medan Estate aims to regulate various activities in the student field so that learning activities in the school can run smoothly, orderly and orderly so that the achievement of the ILMI 
SMP-IT Nurul Medan Estate goals to produce an Islamic generation that is not only superior in general insight but also in matters of religious values.

\subsection{Teacher's Potential in Financial Management}

You are all activities related to structuring the sources, uses, accountability of education funds in schools. Teachers are not directly involved in financial management in this school, but there are some teachers who know information about financial expenditure and income in this school.

4.6 Teacher Potential in Management of Facilities and Infrastructure

Facilities and infrastructure management are all structuring processes related to the procurement, utilization and management of educational facilities and infrastructure, in order to achieve the objectives set effectively and efficiently. Educational facilities are a supporting tool for the teaching and learning process.

4.7 Supporting and Inhibiting Factors in School- Based Management (SBM) Implementation in SMP-IT Nurul ILMI Medan Estate

Supporting factors for the implementation of school- based management in SMP-IT Nurul ILMI Medan Estatea are the government, students, and teachers.

- Forms of government support in SMP-IT Nurul ILMI Medan Estate up a financial support through the provision of BOS funds, allocation of funds of local government and the authority in the management of schools.

- Forms of teacher support in the implementation of school-based management in SMP-IT Nurul ILMI Medan Estate which is in the form of teaching staff and S.1 qualified and S.2 qualified staff and there are about $80 \%$ of teachers who have been certified.

- While the form of support for students in the implementation of schoolbased management in SMP-IT Nurul ILMI Medan Estate, namely the number of new student admissions is increasing from previous years.

- The inhibiting factor in the implementation of school-based management in SMP-IT Nurul ILMI Medan Estate, namely:

- The role of the community that is not maximized. The role of the community is very influential on the course of the management of educational institutions and supports and participates in developing the SMP-IT Nurul ILMI Medan Estate school.

- Limited school funding. Funding has an impact that directly determines the effectiveness and efficiency of education. If school funding only relies on assistance from the government, it can be said that it is still inadequate, so schools with their creativity need to find other funding sources.

\section{Conclusions, Implications And Suggestions}

\subsection{Conclusions}

Based on the exposure of the data and a description of the discussion of the results of the research described in the previous chapter, the conclusions of this study are as follows :

- The results of applying SBM at SMP-IT Nurul ILMI Medan Estate are effective because the results obtained from the implementation of SBM can support the achievement of school programs. 
- $\quad$ Empowerment of potential teachers in SMP-IT Nurul ILMI Medan Estate is well implemented this is seen in terms of teacher potential in curriculum management, potential in effective learning management, teacher potential in workforce and student affairs, teacher potential in financial management, and teacher potential in facilities and infrastructure.

- Teachers are included whenever there are activities or programs that support the school for the better and school goals can be achieved.

- Factors supporting the implementation of school-based management, namely the government, teachers and students. While the inhibiting factors are the role of the community that has not been maximized and the limitations of school funds.

\subsection{Implications}

With the cooperation between teachers and staff and the Principal, the management of the curriculum and infrastructure will run well and the school's objectives can be achieved. Management of school finance does need to involve teachers. Financial transparency needs to be done to avoid teacher suspicions to the Principal. The management of school finance is not just the principal and treasurer, but the teacher also needs to be involved in school finance.

The role of teachers in student affairs and workforce needs to be empowered. Teachers at SMP-IT Nurul ILMI Medan Estate in terms of student affairs have been actively involved. The involvement of teachers in student affairs includes participation in the admission committee of new students at SMP-IT Nurul ILMI Medan Estate. In terms of workforce, teachers also participated in the matter of attending trainings to improve teacher professionalism. Head of SMP-IT Nurul ILMI Medan Estate must be able to continue to empower teachers. Empowerment can be done by continuing to activate the participation of teachers to improve their education, and providing learning media for teachers to use in teaching and learning activities.

\subsection{Suggestion}

From the conclusions and implications outlined above, some suggestions for implementing school- based management are generated in the empowerment of teacher potential, namely:

For the teacher. Teachers are expected to be able to improve the implementation of SBM so as to further improve the quality of education by fostering interest and desire to improve themselves to be better.

For Principals. It is expected to be able to advise teachers to improve the implementation of SBM so that it can improve the quality of education and always motivate teachers to not give up easily and always innovate.

\section{References} $\begin{array}{ccccc}\text { Siti } & \text { Makhmudah. (2016). Upaya } & \text { Memperbaiki Kualitas } & \text { Guru Dengan } \\ \text { Memaksimalkan Terpenuhinya Kompetensi } & & \end{array}$

Kepribadian Dan Profesionalisme Guru. Jurnal Studi Islam, Volume 11, No. 1 April 2016. Hasibuan, Malayu S.P, (2004). Manajemen: Dasar, Pengertian, dan Masalah, Jakarta: 
Bumi Aksara, cet. 3. E. Mulyasa, (2003). Manajemen Berbasis Sekolah”, Jakarta: Rosda, cet. ke- 3,h.11.

Undang-undang no. 20 tahun (2003) tentang Sistem Pendidikan Nasional, BAB II Pasal 3.

Yurni Rahman. (2018). Evaluation of School-Based Management (SBM) Implementation in Basic School Using Context, Input, Process, and Product Models. Advances in Social Science, Education and Humanities Research (ASSEHR), volume 244.

Hutabarat, Wesly. (2015). Implementation of School Based Management in Indonesia (Affecting Work Motivation, Job- Satisfaction, and Teacher Job- Performance) International Journal of Sciences: Basic and Applied Research (IJSBAR) Volume 22, No 2, pp 428-440.

Bahr, Nan, at.al. (2007). Potency in professional development for teachers. In Australian Association for Research in

Education International Education Research Conference: Research Impacts: Proving or improving?, 25-29 November 2007, Perth. (Unpublished).

Siti Supeni. (2017). Implementation Of Local Content Curriculum About Local Potency In Realizing Local Building Based On Sida (Local Innovation System Of Wonogiri Regency) Proceedings ICTESS UNISRI 2017 ISSN: 2549- 094x Vol 1, Number 1, January 2017.

Ambarita, Biner. Nasrun. (2016). Manajemen Pendidikan dan Peningkatan Mutu. Alfabeta. Bandung. pg.56-60 http://lpmp- sumut.kemdikbud.go.id/pmp/pages/main.php?page= smp. 